\title{
INFLUENCE OF FIBREGLASS MESH ON PHYSICAL PROPERTIES OF LIGHTWEIGHT FOAMCRETE
}

\author{
Anisah Mat Serudin, Md Azree Othuman MYdin* \\ AND AbDUl NaSer AbDUl GHANI \\ School of Housing, Building and Planning, Universiti Sains Malaysia, \\ 11800, Penang, Malaysia \\ *Corresponding author: azree@usm.my
}

(Received: 12 $2^{\text {th }}$ April 2020; Accepted: 27th September 2020; Published on-line: $4^{\text {th }}$ January 2021)

\begin{abstract}
This research project was designed to investigate the influence of fibremesh on the durability properties of lightweight foamcrete (LFC). The fibremesh, categorized as a synthetic fibre (man-made fibre), was used for this study. It poses a continuous fibre with warp and weft structure that was used as confinement material in this investigation where four different weights per area $\left(\mathrm{g} / \mathrm{m}^{2}\right)$ of the fibremesh were observed namely, $110 \mathrm{~g}, 130 \mathrm{~g}, 145 \mathrm{~g}$, and $160 \mathrm{~g}$. Three experimental tests were involved in this preliminary study: porosity, water absorption, and drying shrinkage test. All the specimens were confined with 1-layer fibremesh at a constant density of $1100 \mathrm{~kg} / \mathrm{m}^{3}$ of LFC and the result was compared with the control (unconfined LFC). The $160 \mathrm{~g} / \mathrm{m}^{2}$ of fibremesh significantly improved the physical properties of LFC where $13.8 \%, 20 \%$, and $57.4 \%$ enhancement was obtained for the porosity, water absorption, and drying shrinkage result, respectively.
\end{abstract}

ABSTRAK: Projek penyelidikan ini dijalankan bagi menyiasat kesan pengunaan jejaring sabut pada sifat ketahanan konkrit ringan berbusa (LFC). Jejaring sabut yang digunakan dalam kajian ini adalah jejaring gentian kaca tahan-alkali yang dikategorikan sebagai serat sintetik yang juga dikenali sebagai fabrik tekstil. Ia mempunyai serat yang panjang dan bersambung dengan struktur yang lekuk dan renda yang digunakan sebagai penambahbaikan bagi konkrit ringan berbusa. Terdapat empat berat jejaring sabut yang diuji iaitu $110 \mathrm{~g}, 130 \mathrm{~g}, 145 \mathrm{~g}$, dan $160 \mathrm{~g}$. Tiga jenis eksperimen bagi kajian awal ini iaitu keliangan, penyerapan air, dan pengecutan pengeringan. Semua spesimen dibalut dengan 1 lapisan jejaring sabut pada $1100 \mathrm{~kg} / \mathrm{m}^{3}$ LFC dan data yang diperoleh dibandingkan dengan spesimen yang tidak dibalut dengan gentian kaca berjejaring. Jejaring sabut 160 $\mathrm{g} / \mathrm{m}^{2}$ meningkatkan sifat fizikal konkrit ringan berbusa di mana $13.8 \%, 20 \%$, dan $57.4 \%$ peningkatan diperoleh bagi keliangan, penyerapan air, dan pengecutan pengeringan, masing-masing.

KEYWORDS: foamed concrete; property; fibremesh; confinement

\section{INTRODUCTION}

From ancient times, concrete has been well known as the most popular material utilized in the worldwide construction industry. It is used in construction work to fulfil the high demand for housing, high-rise building, infrastructure, etc. This is because concrete is resistant to deterioration compared to wood, and it is also easier to build in several forms. Presently, the application of an air cell system becomes one of the preferable technologies to be used in a construction project due to its benefits. It is getting more attention since it has the ability to reduce the size of the foundation and structural dead load due to its low 
density, thus minimizing operating costs and labour use [1,2]. It is also acknowledged as a sustainable building material $[3,4]$. High flowability concrete, namely, lightweight foamcrete (LFC) has a varied range of density and can be constructed to any desired application such as wall panels, slabs, or other load-bearing building elements, lightweight concrete block, void filling, etc. [5].

The density of LFC typically ranges between $300 \mathrm{~kg} / \mathrm{m}^{3}$ to $1600 \mathrm{~kg} / \mathrm{m}^{3}$ [6] which is $20 \%$ and up to $85 \%$ of its volume filled with air-void. These air-voids were created by the introduction of foam into the cement slurry or mortar causing its unit weight (density) to be lower than that of normal concrete where the density ranges between $2240 \mathrm{~kg} / \mathrm{m}^{3}$ and $2400 \mathrm{~kg} / \mathrm{m}^{3}$ [7]. However, when a high volume of foam is added into the mortar, more airvoids will be created in the mortar slurry, thereby inducing a higher porosity, water absorption, and shrinkage in the LFC. According to Shabbar et al. [8], 60 to $90 \%$ of LFC volume is pore space where the pore size and microstructure influenced its physical properties. Kurpińska and Ferenc [9] also reported that the high percentage of porosity in LFC is due to the void contents of the composite being higher, while Hilal et al. [10] clarified that the higher percentage of porosity is obtained at the lower density of LFC. Besides, Thakrele [11] also mentioned that water absorption is higher because of the higher air content in the LFC. In addition, the major drawbacks of this LFC material are the high drying shrinkage behaviour, which is 4 to 10 times higher than normal weight concrete [12]. Rai and Kumar [13] verified that this happened due to the no coarse aggregate used in the mixture that resulted in the high drying shrinkage obtained, which will lead to the low strength characteristic of LFC. Many researchers have done the study of enhancement of the properties of LFC by the inclusion of short fibres such as sisal fibres [14], kenaf fibres [15-17], oil palm fibres [15,18], polypropylene fibres [15,16], and AR-glass and steel fibres [15]. However, some of the materials have a negative impact on the long-term performance of LFC such as deterioration of natural fibre [19], and corrosion of the reinforcing steel [20]. Thus, in this research, authors have explored the potentiality of continuous fibres, namely, fibremesh, as an enhancement to the properties of LFC, this has not being practiced yet in such types of concrete. In this research, the authors examined the influence of different weight per area $\left(\mathrm{g} / \mathrm{m}^{2}\right)$ of fibremesh-confined LFC to improve its porosity, water absorption, and drying shrinkage performance since it is correlated to the mechanical properties of the composite. The fibremesh used in this research is alkali-resistant (AR) fibremesh with four different weights per area $\left(\mathrm{g} / \mathrm{m}^{2}\right)$ which were $110 \mathrm{~g}, 130 \mathrm{~g}, 145 \mathrm{~g}$, and $160 \mathrm{~g}$. This type of fibremesh is more flexible, easy to handle, cheaper, and has higher performance compared to others (carbon, aramid, etc.).

\section{MATERIAL PREPARATION}

To prepare the LFC mix, four (4) common materials were utilized in the production: cement, sand, water, and stable foam. Furthermore, four different weights per area $\left(\mathrm{g} / \mathrm{m}^{2}\right)$ of fibremesh were utilized in this study, namely, $110 \mathrm{~g}, 130 \mathrm{~g}, 145 \mathrm{~g}$, and $160 \mathrm{~g}$. All the results obtained from respective LFC specimens confined with 1-layer of the different weights per area of fibremesh were compared to the control specimens (LFC without any reinforcement). For this particular research, Ordinary Portland Cement (OPC) was used which is in accordance with the specifications of Type 1 Portland Cement in ASTM C15004 [21]. Sand particle size utilized in this research is less than $1.18 \mathrm{~mm}$ diameter with the specific gravity of 2.74 and fineness modulus of 1.35 . The grading limits are according to ASTM C778-06 [22]. Fine aggregate is suitable for producing the LFC since the coarse aggregate caused the existence of bigger pores and created an inconsistent mix that affected the LFC properties. The presence of water is necessary to mix the cement and fine 
aggregate to form the cement slurry through chemical reaction which will lead to the hardened of mortar paste. Tap water (free from any harmful substance) was used which complied with the standard stated in ASTM C1602-C05 [23]. Foam was added to control and obtain a desirable density for the LFC. In this study, a protein-based foaming agent, namely, NORAITE PA-1 was used to produce a stable foam. $1 \mathrm{~kg}$ of foaming agent was diluted into $30 \mathrm{~L}$ of water.

\section{MIX PROPORTION AND EXPERIMENTAL SETUP}

\subsection{Mix Design}

Based on the previous research, there are many factors that influence the behaviour of LFC such as the density of LFC, the water to cement ratio, the binder to cement ratio, the type of filler, the type of foaming agent, the inclusion of fibre, etc. Thus, to obtain comparable results, the mix design of LFC was fixed, as shown in Table 1. Besides, the density of LFC was the major factor that would affect the performance of LFC, so that in this research it was maintained at $1100 \mathrm{~kg} / \mathrm{m}^{3}$. Since the application of LFC can be categorized into structural, semi structural, and non-structural, the intermediate application is more suitable to be chosen for preliminary study.

Table 1: Mix design of LFC mixes confined with fibremesh

\begin{tabular}{cccccccc}
\hline Sample & $\begin{array}{c}\text { Weights per } \\
\text { area of } \\
\text { fibremesh } \\
{\left[\mathbf{g} / \mathbf{m}^{2}\right]}\end{array}$ & $\begin{array}{c}\text { Mix density } \\
\text { of LFC } \\
{\left[\mathbf{k g} / \mathbf{m}^{3}\right]}\end{array}$ & \multicolumn{2}{c}{ Mix ratio of LFC } & \multicolumn{3}{c}{$\begin{array}{c}\text { Mix proportions of LFC, } \\
\mathbf{k g} / \mathbf{m}^{3}\end{array}$} \\
\cline { 5 - 8 } & & & $\begin{array}{c}\text { Cement/ } \\
\text { sand }\end{array}$ & $\begin{array}{c}\text { Water/ } \\
\text { cement }\end{array}$ & Cement & Sand & Water \\
\hline Control & - & 1100 & $1: 1.5$ & 0.45 & 410.79 & 616.18 & 184.86 \\
$110 \mathrm{~g}$ & 110 & 1100 & $1: 1.5$ & 0.45 & 410.79 & 616.18 & 184.86 \\
$130 \mathrm{~g}$ & 130 & 1100 & $1: 1.5$ & 0.45 & 410.79 & 616.18 & 184.86 \\
$145 \mathrm{~g}$ & 145 & 1100 & $1: 1.5$ & 0.45 & 410.79 & 616.18 & 184.86 \\
$160 \mathrm{~g}$ & 160 & 1100 & $1: 1.5$ & 0.45 & 410.79 & 616.18 & 184.86 \\
\hline
\end{tabular}

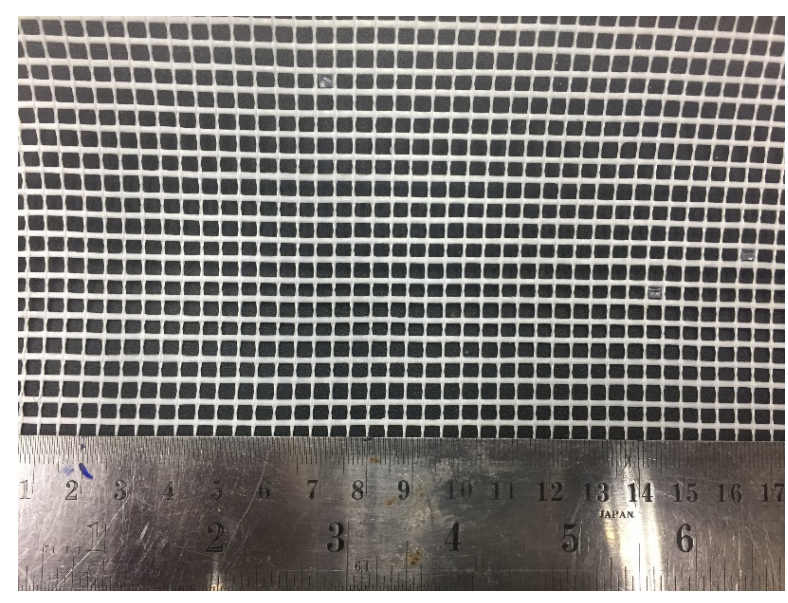

Fig. 1: Physical features of the fibremesh.

As mentioned by [24], 0.45 of water to cement ratio produced an LFC with a reasonable workability. Thus in this research, it was fixed at 0.45 . The filler to cement ratio was fixed to $1: 1.5$ as demonstrated in previous study [15-16, 18, 25-28]. Furthermore, four different weights of fibremesh, namely, $110 \mathrm{~g}, 130 \mathrm{~g}, 145 \mathrm{~g}$, and $160 \mathrm{~g}$ per area $\left(\mathrm{g} / \mathrm{m}^{2}\right)$ were used in this observation. The data obtained from this research would 
be useful for the construction sector or other researchers that are interested in the application of fibremesh in LFC since it has not been documented yet. Figure 1 shows the physical features of the fibremesh and its physical properties is detailed in Table 2.

Table 2: Physical properties of fibremesh

\begin{tabular}{ccccc}
\hline Properties & \multicolumn{4}{c}{ Weight of woven fiberglass mesh $\mathbf{( g / \mathbf { m } ^ { 2 } )}$} \\
\cline { 2 - 5 } & $\mathbf{1 1 0}$ & $\mathbf{1 3 0}$ & $\mathbf{1 4 5}$ & $\mathbf{1 6 0}$ \\
\hline Mesh size & $4.0 \times 5.0 \mathrm{~mm}$ & $4.0 \times 5.0 \mathrm{~mm}$ & $4.0 \times 5.0 \mathrm{~mm}$ & $4.0 \times 5.0 \mathrm{~mm}$ \\
Colour & White & White & White & White \\
Coating type & Alkali resistant & Alkali resistant & Alkali resistant & Alkali resistant \\
Mass $\left(\mathrm{g} / \mathrm{m}^{2}\right)$ & $110 \pm 3$ & $130 \pm 3$ & $145 \pm 3$ & $160 \pm 3$ \\
Ignition point & $391^{\circ} \mathrm{C}\left(735.8^{\circ} \mathrm{F}\right)$ & $394^{\circ} \mathrm{C}\left(741.2^{\circ} \mathrm{F}\right)$ & $398^{\circ} \mathrm{C}\left(784.4^{\circ} \mathrm{F}\right)$ & $404^{\circ} \mathrm{C}\left(759.2^{\circ} \mathrm{F}\right)$ \\
Melt point & $154^{\circ} \mathrm{C}\left(309.2^{\circ} \mathrm{F}\right)$ & $156^{\circ} \mathrm{C}\left(312.8^{\circ} \mathrm{F}\right)$ & $158^{\circ} \mathrm{C}\left(316.4^{\circ} \mathrm{F}\right)$ & $160^{\circ} \mathrm{C}\left(320.0^{\circ} \mathrm{F}\right)$ \\
Tensile strength (MPa) & 1195 & 1250 & 1325 & 1407 \\
Elongation at break $(\%)$ & $4.15 \%$ & $3.75 \%$ & $3.41 \%$ & $3.07 \%$ \\
Compliance & ASTM C1116-02 & ASTM C1116-02 & ASTM C1116-02 & ASTM C1116-02 \\
Quality assured facility & ISO $9001: 2008$ & ISO 9001:2008 & ISO 9001:2008 & ISO 9001:2008 \\
\hline
\end{tabular}

\subsection{Water Absorption Test}

The water absorption test was determined as prescribed in BS 1881-122 [29]. Cylindrical-shaped specimens $(75 \mathrm{~mm} \varnothing \times 100 \mathrm{~mm} \mathrm{~h})$ were used in this study. At the aging day of the test, 3 specimens were unwrapped and oven-dried for 72 hours. Then, the weights of the cooled oven-dried specimens were recorded as $W_{d}$, and they were fully submerged in a water tank for 30 minutes (refer Fig. 2). Next, a dry cloth was used to remove any excess water present on the test specimens and their weight was recorded in a saturated condition $W s$. The water absorption was expressed in percentage, $W a$, and calculated using Equation (1). The average of these 3 specimens was taken as the final result for the water absorption test.

$$
\text { Water absorption }(\%), W_{a}=\left(\frac{W_{s}-W_{d}}{W_{d}}\right) \times 100 \%
$$

Where, $W_{s} \quad=$ Saturated surface dry weight

$W_{d} \quad$ = Oven-dried weight

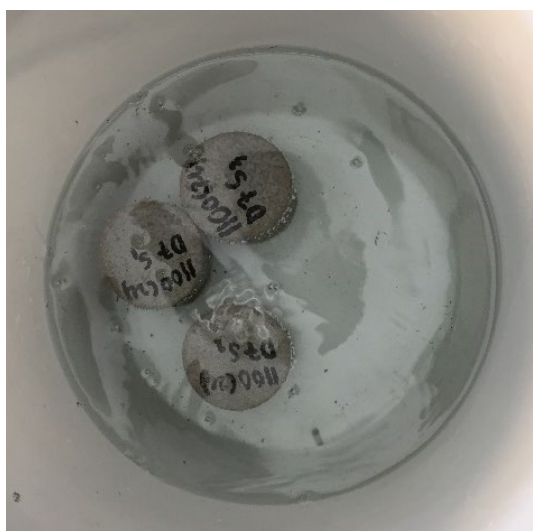

(a)

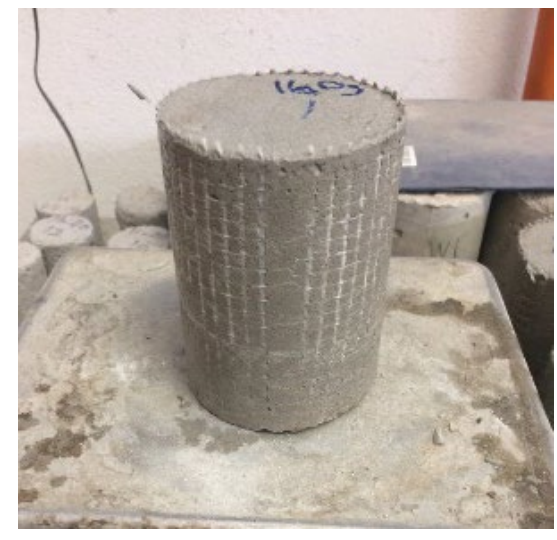

(b)

Fig. 2 :Water absorption test. (a) LFC specimens were fully submerged in a water tank, (b) Side view of LFC specimen. 


\subsection{Porosity Test}

The porosity test was conducted based on the method described in RILEM [30]. This test was determined by the immersion method into a vacuum desiccator and tested on day 28. The purpose of this test was to determine the percentage of air-voids in the LFC specimens confined with different weights per area $\left(\mathrm{g} / \mathrm{m}^{2}\right)$ of fibremesh. As mentioned by previous researchers, LFC (without any reinforcement) possesses a high porosity compared to the LFC specimens with reinforcement. Thus, the confinement of fibremesh in the LFC will decrease the percentage of porosity contained. Therefore, 3 specimens of LFC, with a diameter of $45 \mathrm{~mm}$ and height of $50 \mathrm{~mm}$, were placed in an oven to remove moisture for 72 hours or until no changes in weight were recorded. Then, the specimens were cooled and their weights recorded as $W_{d r y}$. The specimens were fully immersed in the vacuum chamber for 72 hours or up until no visible bubbles appeared. The weights of the specimens in water $\left(W_{s, w}\right)$ and in air $\left(W_{s, a}\right)$ were recorded. Figure 3 shows the setup of the vacuum desiccator for the test, while Eq. (2) was used to measure the percentage of porosity in LFC. The average value of the 3 specimens was recorded as the final result for the total porosity test.

$$
\text { Total porosity }(\%)=\left(\frac{W_{s, a}-W_{d r y}}{W_{s, a}-W_{s, w}}\right) \times 100 \%
$$

$$
\text { Where, } \quad \begin{array}{ll}
W_{s, a} & =\text { weight of saturated sample in air } \\
W_{d r y} & =\text { weight of oven-dried sample } \\
W_{s, w} & =\text { weight of the saturated sample in water }
\end{array}
$$

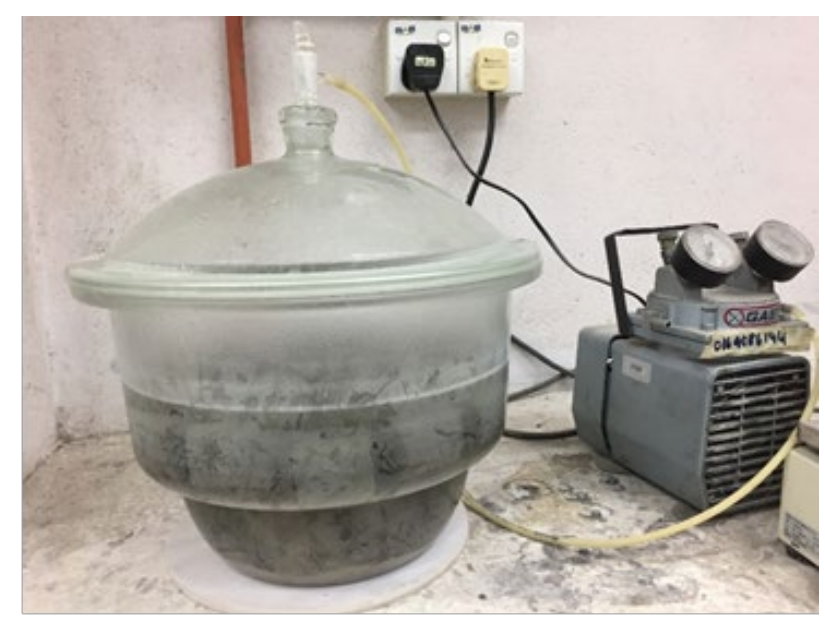

Fig. 3: Porosity test.

\subsection{Shrinkage Test}

Drying shrinkage test was measured via Mitutoyo brand digital indicator with 298 $\mathrm{mm}$ of reference bar and it was performed according to ASTM C157/C157M [31], where 3 prism specimens with size of $75 \times 75 \times 285 \mathrm{~mm}$ were installed with a pair of steel screws and cap nuts. After demoulding, LFC specimens were placed in the length comparator, as seen in Fig. 4, and rotated anti-clockwise to obtain the data. The readings were taken and recorded as, $(L i) . L i$ is the corrected initial comparator reading. Then, the steps were repeated for the next testing ages, which were at days 1, 3, 7, 14, 21, 28, and 56 . These readings were recorded as $L x$, where $x$ represents the test at the subsequent ages. The drying shrinkage was calculated using Eq. (3), where the corrected comparator 
reading was equal to the specimen comparator reading minus the reference bar comparator reading.

$$
\text { Drying shrinkage, }(\mathrm{mm})=\left(\frac{L_{x}-L_{i}}{285}\right) \times 100 \%
$$

$$
\text { Where, } \quad \begin{array}{ll}
L_{x} & =\text { corrected comparator reading } \\
L_{i} & =\text { corrected initial comparator reading } \\
x & =\text { day test }
\end{array}
$$

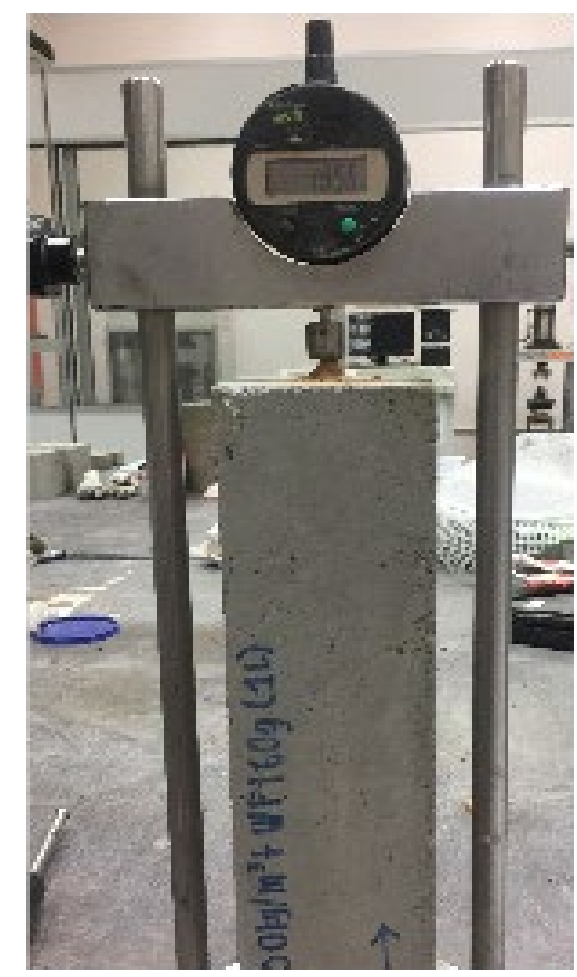

Fig. 4: Setup for drying shrinkage test.

\section{RESULTS AND DISCUSSION}

\subsection{Porosity}

The porosity test was conducted using the vacuum saturation approach in accordance to RILEM. As verified by Hilal et al. [10], this method provides the most appropriate means of accurately assessing the porosity of LFC compared to mercury intrusion porosimetry (MIP) and apparent porosity techniques. This is because the MIP method only determines the entrained pores with diameters of less than $400 \mu \mathrm{m}$, while the apparent porosity approach is unsuitable as the contribution of water absorption is only applied for the capillary pores, which depend on the paste content, and the entrained pores (air-voids) do not take part in this test as they are not interlocked [10]. As shown in Fig. 5, the control specimen showed the highest porosity when compared with the other specimens, which had been confined with different weights per area $\left(\mathrm{g} / \mathrm{m}^{2}\right)$ of fibremesh. The porosity decreased as the weight per area $\left(\mathrm{g} / \mathrm{m}^{2}\right)$ of the fibremesh increased. As illustrated in Table 3 , the porosity decreased from $5.7 \%$ to $13.8 \%$ when the LFC specimens were confined with $110 \mathrm{~g} / \mathrm{m}^{2}$ to $160 \mathrm{~g} / \mathrm{m}^{2}$ of fibremesh, respectively. This was due to the confinement effect of the fibremesh which had reduced the rate of the water penetrated into the air void 
of LFC on the same day the measurements were taken. The presence of the fibremesh impeded the water movement into the paste phase of the LFC. This explained the reason for the control specimen having a higher porosity compared to all the other specimens. Besides, from the previous studies, no research has yet been done to investigate the porosity of LFC confined by fibremesh. In this experimental investigation, it was observed that the LFC that was confined with fibremesh showed the same decreasing pattern for porosity as with the inclusion of fibres (short fibres such as sisal, kenaf, oil palm, polypropylene, steel, etc.). For instance, based on a study conducted by Zamzani [27], the inclusion of $0.1 \%$ to $0.6 \%$ of Cocos nucifera Linn. (CNF) fibre by volume fraction in LFC $\left(1450 \mathrm{~kg} / \mathrm{m}^{3}\right)$ was able to decrease the porosity from $3 \%$ to $13 \%$ at day-28 compared to the control. This result was approximately similar to the result obtained in the current research, where the confinement of LFC with $110 \mathrm{~g} / \mathrm{m}^{2}$ to $160 \mathrm{~g} / \mathrm{m}^{2}$ improved the porosity by $5.7 \%$ to $13.8 \%$ compared to the control, which was without any confinement. Therefore, the confinement of the LFC specimens with $160 \mathrm{~g} / \mathrm{m}^{2}$ of fibremesh showed the best result as it reduced the porosity up to $13.8 \%$, as obtained in this research.

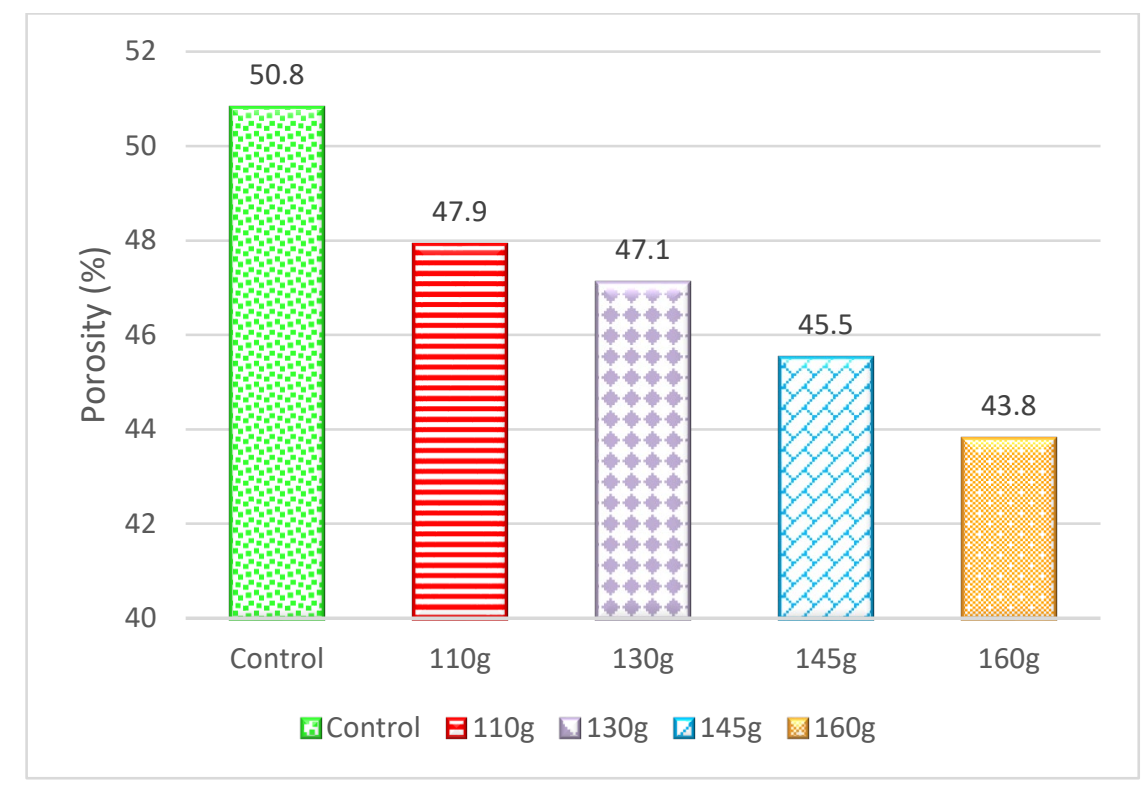

Fig. 5: Porosity of LFC specimens confined with different weights per area $\left(\mathrm{g} / \mathrm{m}^{2}\right)$ of fibremesh at day-28.

Table 3 Percentage decrease in porosity for confined LFC specimens compared to the control specimen

\begin{tabular}{cc}
\hline Specimen & Percentage decrease (\%) \\
\hline $110 \mathrm{~g}$ & 5.7 \\
$130 \mathrm{~g}$ & 10.4 \\
$145 \mathrm{~g}$ & 13.4 \\
$160 \mathrm{~g}$ & 13.8 \\
\hline
\end{tabular}

\subsection{Water Absorption}

Water absorption occurs as a result of capillary pores in the LFC cement paste [32]. Figure 6 shows the water absorption capacity of the LFC specimens confined with different weights per area of fibremesh and of the control specimen as a reference sample. Overall, the control specimen possessed a relatively high-water absorption capacity 
compared to the specimens confined with fibremesh. Theoretically, the water absorption happened due to the process whereby the concrete absorbed or drew water into its pores and capillaries [33]. It could be seen that the higher weight per area of fibremesh contributed to a greater reduction in the water absorption capacity of all the specimens that were tested in this research. As shown in Table 4, the water absorption capacity of the specimens confined with $110,130,145$, and $160 \mathrm{~g} / \mathrm{m}^{2}$ of fibremesh decreased by $6.5 \%$, $7.6 \%, 14.1 \%$ and $20.0 \%$, respectively when compared to the control specimen. The reduction in the water absorption capacity of the LFC specimens was due to the enclosed fibremesh array that managed to prevent the penetration of water into the cement matrix. Besides, fibremesh possesses a hydrophobic characteristic where it provides an alternative solution for inhibiting the diffusion of water molecules into a cement matrix, which is contrary with the behaviour of natural fibres that tended to attract water due to their hydrophilic nature [17]. Thus, this investigation proved that the $160 \mathrm{~g} / \mathrm{m}^{2}$ of fibremesh led to a reduction in the water absorption properties of LFC.

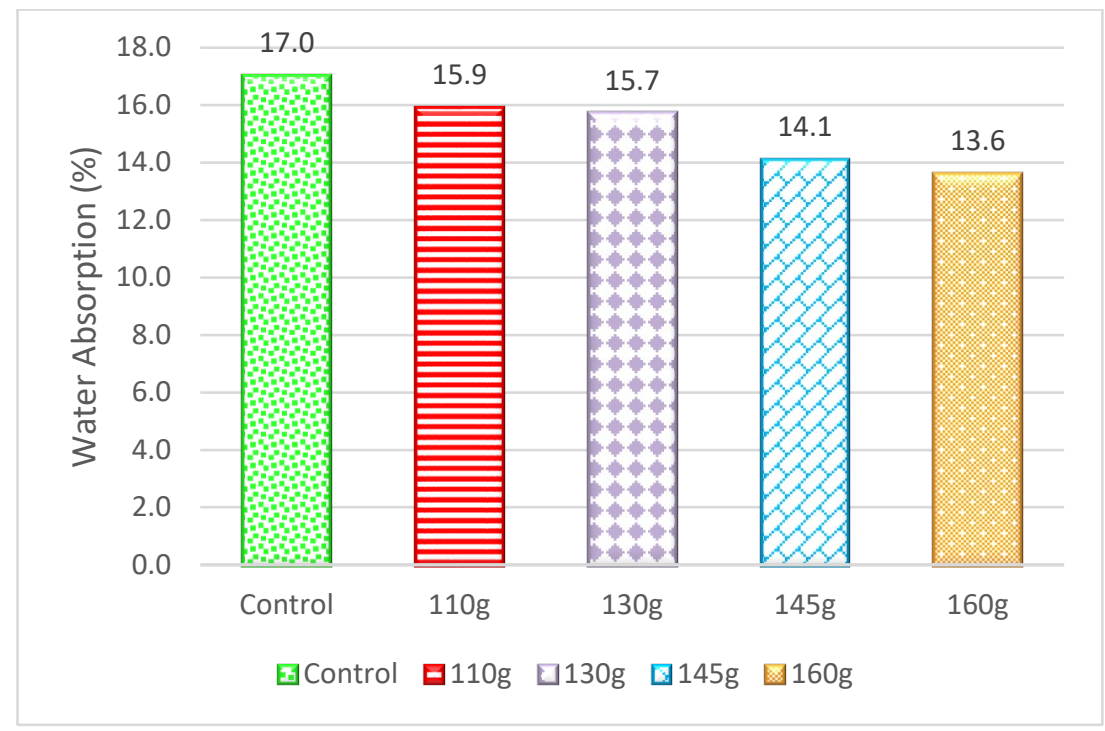

Fig. 6: Water absorption capacity of LFC specimens confined with different weights per area $\left(\mathrm{g} / \mathrm{m}^{2}\right)$ of fibremesh at day-28.

Table 4: Percentage decrease in water absorption capacity for confined specimens compared to the control specimen

\begin{tabular}{cc}
\hline Specimen & Percentage decrease (\%) \\
\hline $110 \mathrm{~g}$ & 6.5 \\
$130 \mathrm{~g}$ & 7.6 \\
$145 \mathrm{~g}$ & 14.1 \\
$160 \mathrm{~g}$ & 20.0 \\
\hline
\end{tabular}

\subsection{Drying Shrinkage}

Amran et al. [1] claimed that the drying shrinkage in LFC is ten times higher compared to normal weight concrete because of the absence of coarse aggregates. According to Cheah et al. [32], drying shrinkage occurs in a cement matrix due to the evaporation of internal free water from the concrete or mortar in the hardened state to the surrounding environment. Based on the test results shown in Fig. 7, the control specimen exhibited a 
higher drying shrinkage compared to the other specimens. This was because the confinement of fibremesh reduced the drying shrinkage behaviour in LFC specimens as the fibremesh was able to maintain the water content and delay the evaporation of the internal moisture, hence lessening the drying shrinkage behaviour. Falliano et al. [34] also proved that unreinforced specimens exhibit a shrinkage that decreases with increasing dry density. Besides, Namsone et al. [35] also stated that the addition of fibre can reduce the risk of shrinkage and stabilize the fresh mix. There was a significant improvement in the drying shrinkage behaviour of the LFC specimens confined with fibremesh, as displayed in Table 5. When the LFC specimen was confined with $110 \mathrm{~g} / \mathrm{m}^{2}$ of fibremesh, the drying shrinkage behaviour was enhanced by $34.4 \%$ compared to the control specimen. The improvement of the drying shrinkage behaviour rose as the weight per area of the fibremesh increased. Consequently, $160 \mathrm{~g} / \mathrm{m}^{2}$ of fibremesh showed the best drying shrinkage prevention, where the drying shrinkage was reduced up to $57.4 \%$ compared to the control specimen.

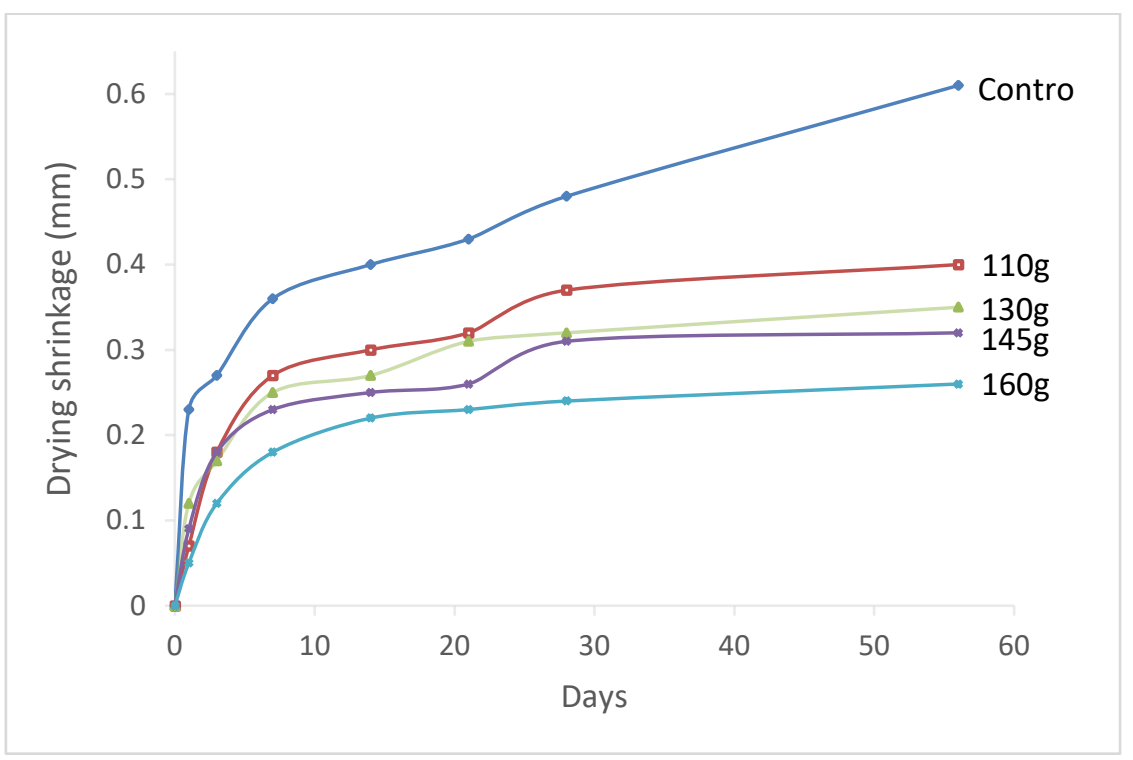

Fig. 7: Drying shrinkage of LFC specimens confined with different weight per area $\left(\mathrm{g} / \mathrm{m}^{2}\right)$ of fibremesh.

Table 5: Percentage decrease of drying shrinkage for confined specimens compared to the control specimen.

\begin{tabular}{cc}
\hline Specimen & Percentage decrease (\%) \\
\hline $110 \mathrm{~g}$ & 34.4 \\
$130 \mathrm{~g}$ & 42.6 \\
$145 \mathrm{~g}$ & 47.5 \\
$160 \mathrm{~g}$ & 57.4 \\
\hline
\end{tabular}

\section{CONCLUSION}

In this preliminary study, the influence of fibremesh on the physical properties of LFC with a density of $1100 \mathrm{~kg} / \mathrm{m}^{3}$ was investigated. Based on the results obtained, the following conclusions can be drawn:

- Overall, the confinement of fibremesh significantly enhanced the physical properties of LFC. 
- Obviously shown in the three experiment tests (porosity, water absorption, and drying shrinkage), the confinement of $160 \mathrm{~g}$ of fibremesh resulted in improvement of the physical properties of LFC.

- It is proven that the weight per area of fibremesh influenced the physical properties of LFC.

- As recommendation for future study, authors suggest to investigate the effect of different types of textile fibres such as carbon, aramid, basalt, etc., to be utilized as confinement material for LFC since it is not covered in this research. They also suggested cost effectiveness analysis between the mentioned textile fabrics to examine which materials give greater benefits to the construction sector.

\section{ACKNOWLEDGEMENT}

The authors would like to thank Universiti Sains Malaysia for their funding of this research through the Bridging Grant: Grant No: 304/PPBGN/6316230.

\section{REFERENCES}

[1] Amran YHM, Farzadnia N, Ali AAA. (2015). Properties and applications of foamed concrete; A review. Construction and Building Materials, 101: 990-1005.

https://doi.org/10.1016/j.conbuildmat.2015.10.112

[2] Fu Y, Wang X, Wang L, Li Y. (2020). Foam Concrete : A State-of-the-Art and State-of-thePractice Review. Advances in Materials Science and Engineering. https://doi.org/10.1155/2020/6153602

[3] Moon AS, Varghese V, Waghmare SS. (2015). Foam Concrete as A Green Building Material. International Journal for Research in Emerging Science and Technology, 2(9): 2532.

[4] Siram KKB, Raj KA. (2013). Concrete + Green = Foam Concrete. International Journal of Civil Engineering and Technology (IJCIET), 2(2): 1-24.

[5] Sari KAM, Sani ARM. (2017). Applications of Foamed Lightweight Concrete. MATEC Web of Conferences, 97: 1-5. https://doi.org/10.1051/matecconf/20179701097

[6] Jalal MD, Tanveer A, Jagdeesh K, Ahmed F. (2017). Foam concrete. International Journal of Civil Engineering Research, 8(1): 1-14. Retrieved from https://www.ripublication.com/ijcer17/ijcerv8n1_01.pdf

[7] Hedjazi S. (2019). Compressive Strength of Lightweight Concrete. In IntechOpen:1-18. https://doi.org/10.5772/intechopen.88057

[8] Shabbar R, Nedwell P, Wu Z. (2018). Porosity and Water Absorption of Aerated Concrete with Varying Aluminium Powder Content. International Journal of Engineering and Technology, 10(3): 234-238. https://doi.org/10.7763/ijet.2018.v10.1065

[9] Kurpińska M, Ferenc T. (2017). Effect of porosity on physical properties of lightweight cement composite with foamed glass aggregate. ITM Web of Conferences, 15: 06005. https://doi.org/10.1051/itmconf/20171506005

[10] Hilal AA, Thom NH, Dawson AR. (2014). Pore structure and permeation characteristics of foamed concrete. Journal of Advanced Concrete Technology, 12: 535-544. https://doi.org/10.3151/jact.12.535

[11] Thakrele MH. (2014). Experimental study on foam concrete. International Journal of Civil, Structural, Environmental and Infrastructure Engineering Research and Development, 4(1): 145-158.

[12] Elrahman MA, El Madawy ME, Chung SY, Sikora P, Stephan D. (2019). Preparation and characterization of ultra-lightweight foamed concrete incorporating lightweight aggregates. Applied Sciences (Switzerland), 9(7): 1-12. https://doi.org/10.3390/app9071447

[13] Rai A, Kumar M (2017). Experimental Study on Compressive and Split Tensile Strength of Foamed Concrete Using Stone Dust. International Research Journal of Engineering and 
Technology(IRJET), 4(5): 1377-1382. Retrieved from https://www.irjet.net/archives/V4/i5/IRJET-V4I5269.pdf

[14] Dhanunjaya G, Dadapeer ABS, Rafi DM. (2018). An Experimental Study on the Durability Properties of Foam Concrete with Addition of Natural Fibers. International Journal of Scientific Research in Science and Technology, 4(2): 529-536.

[15] Awang H, Ahmad MH. (2014). Durability Properties of Foamed Concrete with Fiber Inclusion. International Journal of Civil, Structural, Construction and Architectural Engineering, 8(3): 273-276.

[16] Hanizam A, Mohammed A, Ahmad MH. (2015). Influence of Kenaf and Polypropylene Fibres on Mechanical and Durability Properties of Fibre Reinforced Lightweight Foamed Concrete. Journal of Engineering Scinece and Technology, 10(4): 496-508. https://doi.org/10.4028/www.scientific.net/AMR.626.404

[17] Mahzabin MS, Hock LJ, Hossain MS, Kang LS. (2018). The influence of addition of treated kenaf fibre in the production and properties of fibre reinforced foamed composite. Construction and Building Materials, 178: 518-528.

[18] Musa M. (2019). Investigation of Durability, Thermal and Mechanical Properties of Oil Palm Empty Fruit Bunch (EFB) Fibre Strengthen Lightweight Foamed Mortar (LFM). Master thesis. Universiti Sains Malaysia.

[19] Bentur A, Mindess S. (2007). Fibre Reinforced Cementitious Composites. In A. Bentur \& S. Mindess (Eds.), Taylor \& Francis (2nd Edition). https://doi.org/10.1016/00104361(79)90446-4

[20] Memon IA, Jhatial AA, Sohu S, Lakhiar MT, Hussain Z. (2018). Influence of Fibre Length on the Behaviour of Polypropylene Fibre Reinforced Cement Concrete. Civil Engineering Journal, 4(9): 2124-2131. https://doi.org/10.28991/cej-03091144

[21] ASTM C150-04 (2004). Standard Specification for Portland Cement C150-04. Annual Book of ASTM Standards, 4(2): 1-8.

[22] ASTM C778-06 (2006). Standard Specification for Standard Sand C778-06. Annual Book of ASTM Standards. Retrieved from http://www.who.int/csr/don/03-june-2016-oropoucheperu/en/

[23] ASTM C1602-C05 (2006). Standard Specification for Mixing Water Used in Production of Hydraulic Cement Concrete C1602. Annual Book of ASTM Standards.

[24] Talaei S, Jafari M, Tarfan S, Hashemlou H. (2014). The Effect of Ratio of Aggregate to Cement Paste Volume on Structural Lightweight Concrete Strength, Viscosity, Density and Cost. Research Journal of Environmental and Earth Sciences, 6(9): 443-450.

[25] Coker EB, Sadiku S, Aguwa JI, Abdullahi M. (2016). Study of the Strength Characteristics of Protein-Based Lightweight Foamed Concrete With Cement Partially Replaced With Rice Husk Ash. Nigerian Journal of Technology, 35(4): 699-706. https://doi.org/10.4314/njt.v35i4.2

[26] Suhaili SS, Mydin MAO. (2020). Potential of stalk and spikelets of empty fruit bunch fibres on mechanical properties of lightweight foamed concrete. International Journal of Scientific and Technology Research, 9(3): 3199-3204.

[27] Zamzani NM. (2019). Characterization of durability and engineering properties of Cocos nucifera Linn Fibre (CNF) reinforced foamcrete and its performance at elevated temperatures. Master thesis. Universiti Sains Malaysia.

[28] Zulkarnain F. (2011). Strength and Durability Properties of Lightweight Foamed Concrete For Housing Construction. Master thesis. Universiti Sains Malaysia.

[29] BS 1881-122 (2011). Testing Concrete Part 122 Method for determination of water absoprtion BS1881-122. British Standard Institution. https://doi.org/10.1017/CBO9781107415324.004

[30] RILEM (1984). Absorption of water by concrete by immersion under vacuum. In RILEM (Ed.), RILEM Recommendations for the Testing and Use of Constructions Materials: 36-37. https://doi.org/doi: 10.1617/2351580117.018

[31] ASTM C157/C157M (2005). Standard Test Method for Length Change of Hardened Hydraulic-Cement Mortar and Concrete. Annual Book of ASTM Standards: 1-10. 
[32] Cheah CB, Lim JS, Ramli MB. (2019). The mechanical strength and durability properties of ternary blended cementitious composites containing granite quarry dust (GQD) as natural sand replacement. Construction and Building Materials, 197(November 2018): 291-306. https://doi.org/10.1016/j.conbuildmat.2018.11.194

[33] Jung CT, Kwong T H, Boon KH. (2018). Water absorption and drying shrinkage of recycled foamed aggregate concrete. Malaysian Journal of Civil Engineering, 30(3): 482-492.

[34] Falliano D, De Domenico D, Ricciardi G, Gugliandolo E. (2019). Compressive and flexural strength of fiber-reinforced foamed concrete: Effect of fiber content, curing conditions and dry density. Construction and Building Materials, 198: 479-493. https://doi.org/10.1016/j.conbuildmat.2018.11.197

[35] Namsone E, Korjakins A, Sahmenko G, Sinka M. (2017). The environmental impacts of foamed concrete production and exploitation. IOP Conference Series: Materials Science and Engineering, 251(1). https://doi.org/10.1088/1757-899X/251/1/012029 